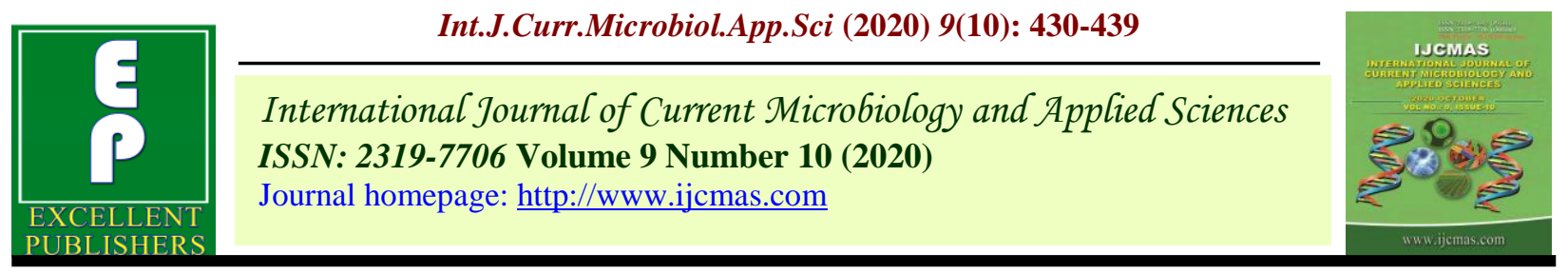

Original Research Article

https://doi.org/10.20546/ijcmas.2020.910.053

\title{
Association of Animal Health Indicators with Welfare Status in Frieswal Cattle at Organized Dairy Herd
}

\author{
Iftekar Rahaman ${ }^{1}$, Rajarshi Samanta ${ }^{2}$, Chittapriya Ghosh ${ }^{3}$, Sanjoy Datta ${ }^{4^{*}}$, \\ Nilotpal Ghosh ${ }^{2}$, Subhasish Biswas ${ }^{5}$ and Subhasish Batabyal ${ }^{6}$
}

${ }^{1}$ Department of ARD, Govt. of West Bengal, ${ }^{2}$ Department of LPM, ${ }^{3}$ Department of LFC, ${ }^{4}$ Department of AGB, ${ }^{5}$ Department of LPT, ${ }^{6}$ Department of Vety. Biochemistry, West Bengal University of Animal and Fishery Sciences, Belgachia, Kolkata-700037, India

*Corresponding author

\section{A B S T R A C T}

Keywords

Animal welfare, Body Condition Score, Hock Lesion Score, Lameness Score, Animal health

\section{Article Info}

Accepted: 07 September 2020 Available Online: 10 October 2020

\begin{abstract}
Forty-two lactating Frieswal cattle divided into three sheds were included for the present study with the objective to assess the welfare status in the conventional barn and to suggest improvement of welfare measures. The health indicators of animals like Body Condition Scores (BCS), Lameness Scores (LS), Hock Lesion Scores (HLS) and Mastitis Incidences (MI) were considered for investigation. The BCS, LS and HLS were determined by scoring system through clinical description, gait, posture and motion based on a 5-point scale. The statistical analysis implied that average BCS for all animals was $2.38 \pm 0.66$, the average LS was recorded as $2.28 \pm 0.66$, whereas, average HLS for all animals was observed as $2.39 \pm 0.65$. Significant $(\mathrm{P}<0.05)$ positive correlations were found between BCS and HLS whereas, highly significant $(\mathrm{P}<0.01)$ positive correlations between BCS and LS, LS and HLS was also recorded. Shed-wise significant $(\mathrm{P}<0.05)$ variations were also reported for BCS, LS and HLS. Higher incidence of mastitis found in the sheds with low cleanliness.
\end{abstract}

\section{Introduction}

The farm level welfare assessment can be used as an advisory tool by farmers, as source of information for management and as a component of quality assurance schemes for consumers. People have high interests in farming and the associated animal welfare standards due to its impact on health and productions of animals and subsequent good impact upon public health. More and more consumers are becoming aware of dairy welfare upon public health, food security and environmental protection. Though this recent interest and concerns about animal welfare are growing day by day, however, the assessment of animal well-being is a complex matter (Rushen et al., 2011). A good welfare is such management where there is no stress which plays an important part in welfare research (Broom et al., 2001). Different methods of on farm monitoring of animal 
welfare have been developed (Johnsen et al., 2001) in Europe. Some of these methods are concerned with design criteria (Bartussek et al., 1999), which comprise of structural and technical elements (space, facilities, etc.) and management-related factors such as hygienic and climatic conditions (Sundrum et al., 1996). Others use animal-based variables or parameters dealing with behaviour, health and physiology of the animals. However, a combination of design and performance criteria is generally recommended to obtain a valid and holistic assessment of animal welfare (Rushen and de Passille 1992, Sandoe et al., 1996, Sundrum et al., 1996). From the economical point of view, the assessment of animal welfare is really important, because it allows in the first stage the detection of imperfections and their correction in the second stage. Thus, retrieval of shortcomings assures the integral development of genetic productive performances by the animal and by the other hand, perfecting the technologies. Thus, evaluation can be based on behavioural, physiological, psychopathological parameters or productive performances. All the indicators have inconveniences and, in this way, most of it is not reliable, used as sole assessment techniques. The BCS (Singh and Singh, 1994), LS (Murray et al., 1996), HLS (Drissler et al., 2005) and mastitis incidences are important health indicators for welfare assessment. Under the present investigation health indicators were taken under consideration to assess the animal welfare condition in the conventional barn with the objectives to assess the welfare standard of dairy cattle in the dairy herd and to suggest improvement of welfare measures of crossbred dairy cattle.

\section{Materials and Methods}

The experiment was conducted from January 2019 to May 2019 at Livestock Farm Complex under the Faculty of Veterinary \& Animal Sciences, West Bengal University of
Animal and Fishery Sciences, Mohanpur Campus, Nadia, West Bengal, India, located at a $22^{\circ} 94^{\prime} \mathrm{N}$ latitude and $88^{\circ} 52^{\prime} \mathrm{E}$ Longitude. Forty-two lactating Frieswal cattles were included for the present investigation. The dairy animals for this study were kept in three sheds, marked as A, B and $\mathrm{C}$ having 15, 11 and 16 animals, respectively. The welfare assessment was carried out based on BCS, LS, HLS and MI. BCS score was prepared (Table 1) from 1 to 5 point scale (Ferguson et al., 1994) based on the clinical condition of the appearance of the spinous and transverse processes of the lumbar vertebrae, the ileal and ischeal tuberosities, the ilio-sacral and ischeal-coccygeal ligaments, and the thurl and tail head regions.

Following the system (Wells et al., 1993), the animals were examined for LS (Table 2) based on their gait and posture. Animals were observed closely during the time when animal was in motion and also at the time of standing condition.

HLS of the animals were estimated (Regula et al., 2004) including skin lesions at the hock region of the animals (Table 3 ). The hock region is the joint area between the tarsal bone and tibial bone, which was examined in naked eye for any presence of lesions.

Mastitis incidents were also recorded for animals in three sheds from health register. The means, standard error and standard deviation for the health indicators under study were computed with the help of standard statistical procedure (Snedecor and Cochran 1968). Modified Duncan's multiple range test was used to test the difference among sub means. Data were analysed by using IBM SPSS 23.0 statistical software to analyse the relationship among the health indicators. Correlation (Pearson's r) analysis was performed to estimate the relationship between different health indicators. The mean significant differences of health indicators 
were estimated by Analysis of variance (ANOVA).

\section{Results and Discussion}

The average BCS for all animals was $2.38 \pm$ 0.66 , the average LS for all animals was recorded as $2.29 \pm 0.66$, whereas, average HLS for all animals was observed as $2.39 \pm$ 0.66 . Nine animals $(21.42 \%)$ scored as very good BCS, where the ischeal or ileal tuberosity was not visible here and the lines between hooks and pins were straight. $11.90 \%$ animals were severely dull which scored greater than 3.5 or 4 and there was a prominent "V" shape between the hooks and pins. Rest of the animals had an average to moderate BCS.

Overall, $19.04 \%$ of all the animals were clinically lame (Lameness score $\geq 3$ ) and two animals were found with inability to bear weight on hind limbs. Prevalence of lameness for individual sheds ranged from 0 to $27.5 \%$, with an interquartile range of 0 to $7.12 \%$. This might be due to poorly designed barn, and animals might have been recovering from acute injuries sustained in that housing system. Animals stand and walk with a normal level back posture were 59.52\%, which scored up to 2 . The prevalence of hair loss ranged from $15.25 \%$ to $22.25 \%$, with an interquartile range of 3.25 to $5.70 \%$. Nine animals exhibited normal to mild hock lesions. Hock lesions were most likely to be still present or healing in all the sheds.

33 animals (78.57\%) had skin lesions on the hock, of which eight animals (19.04\%) had lesions on both legs, $59.52 \%$ had lesions on more than one location on the hock, and $14.28 \%$ (six animals) had lesions with a severity score greater than 3.5 or 4 . Only animals (11.90\%) scored as having swelling of the entire tarsal joint. The prevalence of lesions also varied with respect to location on the hock. Lesions were rarely observed on the medial surface of the tarsal joint. Lesions were more common on the lateral and medial surfaces of the tuber calcis and on the lateral surface of the tarsal joint.

No mastitis incidence was found in the shed A, whereas, four and two incidences of mastitis were recorded in shed $\mathrm{B}$ and $\mathrm{C}$ respectively. Dirty udders in low cleanliness condition could be considered as a potential cause to mastitis in some of the sheds evaluated in this study.

Shed-wise population pyramid regarding BCS, LS and HLS was constructed. The pyramid revealed (Fig. 1) that shed A was having more numbers of animals with Good to Very Good BCS scores followed by shed C and $\mathrm{B}$ respectively. LS was normal to mild in shed A (Fig. 2), followed by shed C and B. In case of the HLS, shed A showed better (Fig. 3 ) condition of the animals followed by shed $\mathrm{C}$ and $\mathrm{B}$.

From statistical analyses, it was observed (Table 4) that mean LS $(1.90 \pm 0.16)$ of shed A differed (Fig. 4) significantly $(\mathrm{P}<0.05)$ from that of shed B $(2.59 \pm 0.18)$ and C (2.44 \pm 0.15 ), whereas the difference of mean (Fig. 5) LS of shed B and C was not significant $(\mathrm{P}<0.05)$. In case of the HLS it was observed (Fig. 6) that mean of shed A $(1.90 \pm 0.14)$ differed significantly $(\mathrm{P}<0.05)$ from that of shed $\mathrm{B}(2.73 \pm 0.17)$ and $\mathrm{C}(2.63 \pm 0.14)$ but difference between shed $\mathrm{B}$ and $\mathrm{C}$ was not found to be significant $(\mathrm{P}<0.05)$.

Correlation (Pearson's r) analysis was performed and scatter-plots were estimated to assess the strength of relationship between different health indicators (Table 5). Significant $(\mathrm{P}<0.05)$ positive correlations were found between BCS with HLS and HLS with LS. Highly significant $(\mathrm{P}<0.01)$ positive correlations between BCS and LS was also 
recorded. Scatter diagrams were constructed to get the pictorial presentation of the correlations (Fig. 7 to 9).

It was noticed that on all the sheds animals were frightened, upset, agitated and expressed discomforts or distress. The cause may be their constant stay in the stall, lack of space, lack of movement and lack of social interactions. In comparison among all the three sheds, animals belonging to shed A were in better welfare condition which revealed well body condition. In a similar study (Garnsworthy et al., 1982), they stated that excessive loss of body condition has been associated with low welfare, there was poor reproductive performance and reduced milk production. Thus, BCS has been receiving considerable attention as a tool to aid in the management of nutritional programs in dairy herds.

Table.1 Criteria used to assign BCS Scores as per clinical description of animals

\begin{tabular}{|c|c|l|}
\hline BCS & Clinical description & \multicolumn{1}{|c|}{ Assessment criteria } \\
\hline $\mathbf{1}$ & Very good & $\begin{array}{l}\text { The ischial or ileal tuberosity is not visible, thick fat at the } \\
\text { thurl and tail head regions, lines between hooks and pins are } \\
\text { straight. }\end{array}$ \\
\hline $\mathbf{2}$ & Good & $\begin{array}{l}\text { The ischial or ileal tuberosity partially visible, the thurl and } \\
\text { tail head regions filled with fat, lines between hooks and pins } \\
\text { are slightly curved. }\end{array}$ \\
\hline $\mathbf{3}$ & Average & $\begin{array}{l}\text { The ischial or ileal tuberosity is round, less fat in the thurl and } \\
\text { tail head regions, lines between hooks and pins are near to u } \\
\text { shaped. }\end{array}$ \\
\hline $\mathbf{4}$ & Poor & $\begin{array}{l}\text { The ischial or ileal tuberosity is angular-round, the thurl and } \\
\text { tail head regions are near to dull condition, the lines between } \\
\text { hooks and pines are close to V shaped. }\end{array}$ \\
\hline $\mathbf{5}$ & \multirow{2}{*}{ Very poor } & $\begin{array}{l}\text { The ischial or ileal tuberosity is angular, the thurl and tail } \\
\text { head regions are in very dull condition, and the lines between } \\
\text { hooks and pines are prominent V shaped. }\end{array}$ \\
\hline
\end{tabular}

Table. 2 Criteria used to assign Lameness Score, of animals

\begin{tabular}{|c|c|l|}
\hline LS & Clinical description & \multicolumn{1}{c|}{ Assessment criteria } \\
\hline $\mathbf{1}$ & Normal & $\begin{array}{l}\text { The animal stands and walks with a level-back posture. Her gait } \\
\text { is normal. }\end{array}$ \\
\hline $\mathbf{2}$ & Mildly lame & $\begin{array}{l}\text { The animal stands with a level-back posture but develops an } \\
\text { arched-back posture while walking. Her gait remains normal. }\end{array}$ \\
\hline $\mathbf{3}$ & Moderately lame & $\begin{array}{l}\text { An arched-back posture is evident both while standing and } \\
\text { walking. Her gait is affected and is best described as short } \\
\text { striding with one or more limbs. }\end{array}$ \\
\hline $\mathbf{4}$ & Lame & $\begin{array}{l}\text { An arched-back posture is always evident and gait is best } \\
\text { described as one deliberate step at a time. The animal favours } \\
\text { one or more limbs/feet. }\end{array}$ \\
\hline $\mathbf{5}$ & Severely lame & $\begin{array}{l}\text { The animal additionally demonstrates an inability or extreme } \\
\text { reluctance to bear weight on one or more of her limbs/feet. }\end{array}$ \\
\hline
\end{tabular}


Table.3 Criteria used to assign Hock Lesion Score to animals

\begin{tabular}{|c|c|l|}
\hline HLS & Clinical Description & \multicolumn{1}{c|}{ Assessment criteria } \\
\hline $\mathbf{1}$ & Normal & There is no visible skin change or absence of lesions. \\
\hline $\mathbf{2}$ & Mild Lesions & Hairless skin is visible at the joint area \\
\hline $\mathbf{3}$ & Moderate Lesions & Swollen condition is found around the joint area. \\
\hline $\mathbf{4}$ & Prominent lesions & Wound can be observed at the joint area. \\
\hline $\mathbf{5}$ & Severe lesions & In severe condition, there is open wound can be observe. \\
\hline
\end{tabular}

Table.4 Shed wise Mean and Standard Error of health indicators

\begin{tabular}{|c|c|c|c|}
\hline $\begin{array}{c}\text { Health } \\
\text { Indicators }\end{array}$ & Shed A & Shed B & Shed C \\
\hline BCS & $2.10^{\mathrm{a}} \pm 0.17$ & $2.50^{\mathrm{a}} \pm 0.19$ & $2.56^{\mathrm{a}} \pm 0.16$ \\
\hline LS & $1.90^{\mathrm{a}} \pm 0.16$ & $2.59^{\mathrm{b}} \pm 0.18$ & $2.44^{\mathrm{b}} \pm 0.15$ \\
\hline HLS & $1.90^{\mathrm{a}} \pm 0.14$ & $2.73^{\mathrm{b}} \pm 0.17$ & $2.63^{\mathrm{b}} \pm 0.14$ \\
\hline
\end{tabular}

* Row wise similar superscripts do not differ significantly $(\mathrm{P}<0.05)$

Table.5 Pearson's Correlation Coefficient (r) between health indicators

\begin{tabular}{|c|c|c|c|}
\hline & BCS & LAMENESS & HLS \\
\hline BCS & - & - & - \\
\hline LAMENESS & $0.510 * *$ & - & - \\
\hline HLS & $0.390^{*}$ & $0.490^{* *}$ & - \\
\hline
\end{tabular}

**Correlation is highly Significant $(\mathrm{P}<0.01)$

* Correlation is Significant $(\mathrm{P}<0.05)$

Fig.1 Shed wise BCS of animals

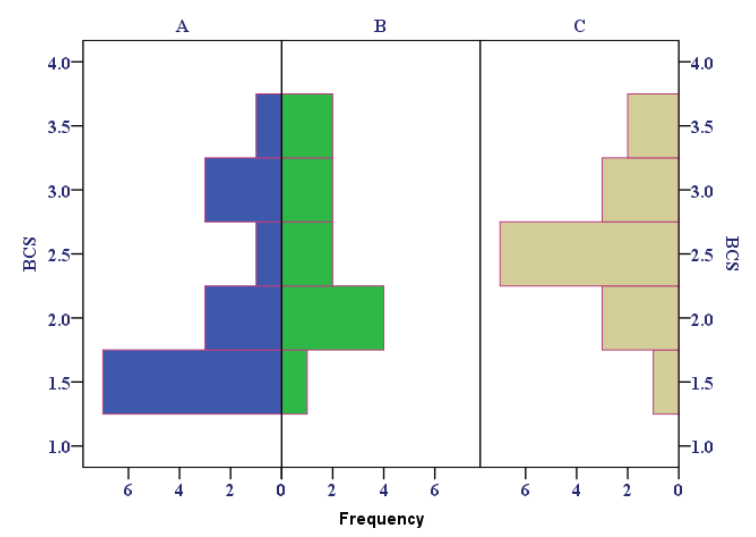

Fig.2 Shed wise Lameness Score of animals

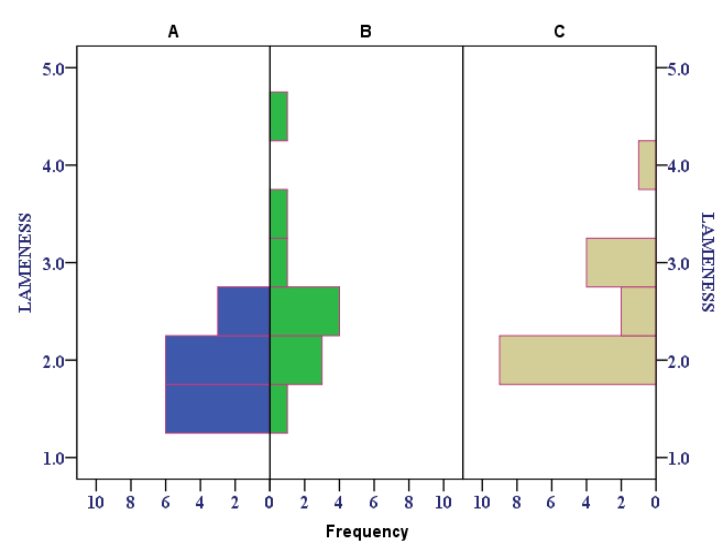


Fig.3 Shed wise HLS of animals

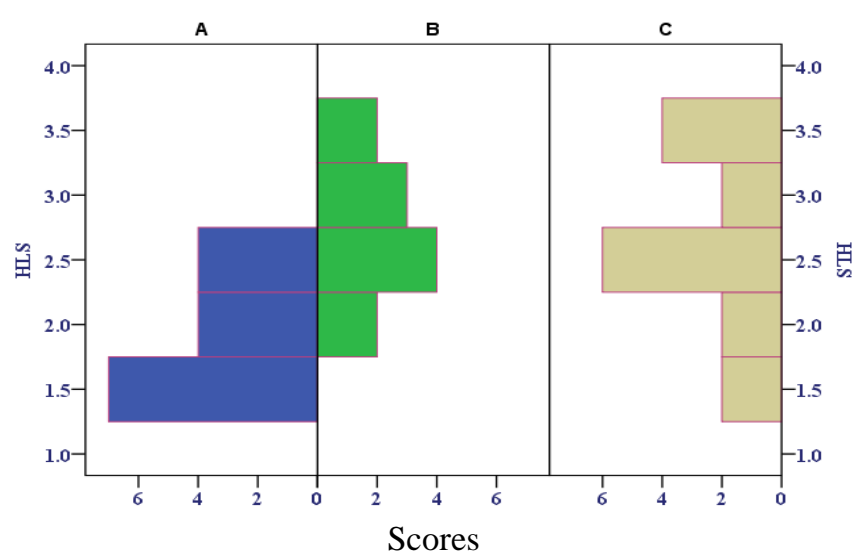

Fig.4 Shed wise mean value of BCS

Fig.5 Shed wise mean value of LS
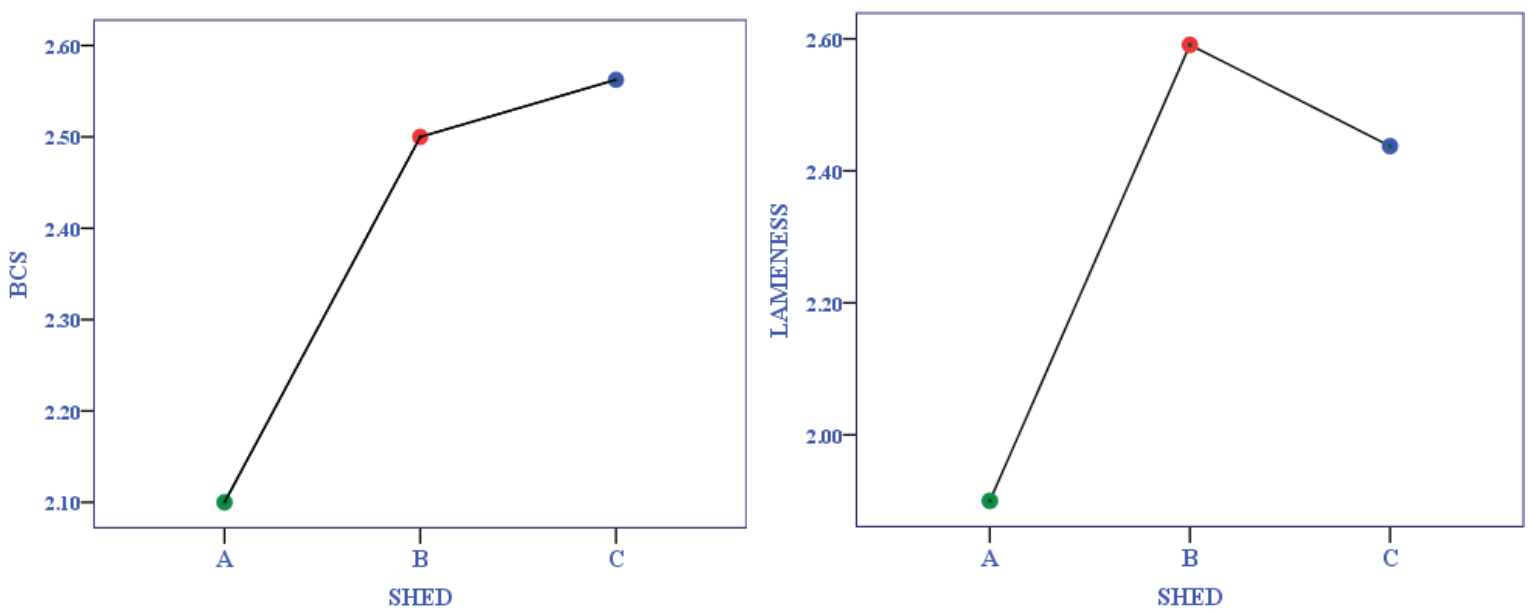

Fig.6 Shed wise mean value of HLS

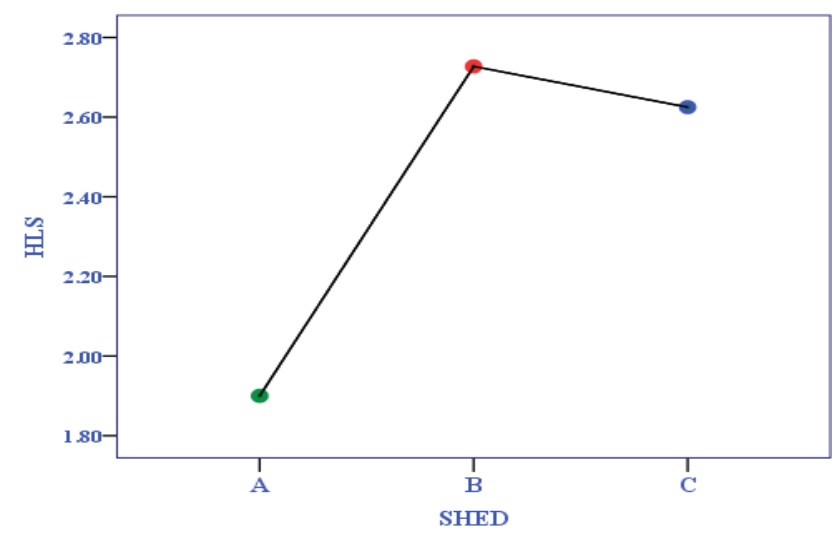


Fig.7 Correlation between LS \& BCS

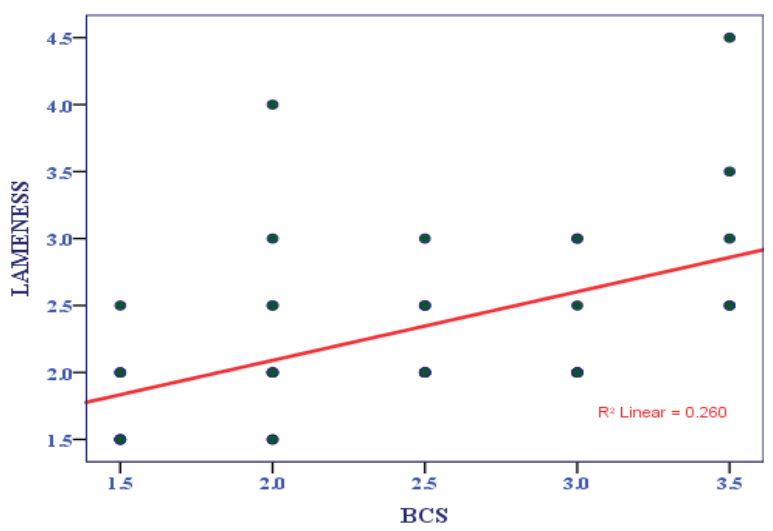

Fig.8 Correlation between HLS \& BCS

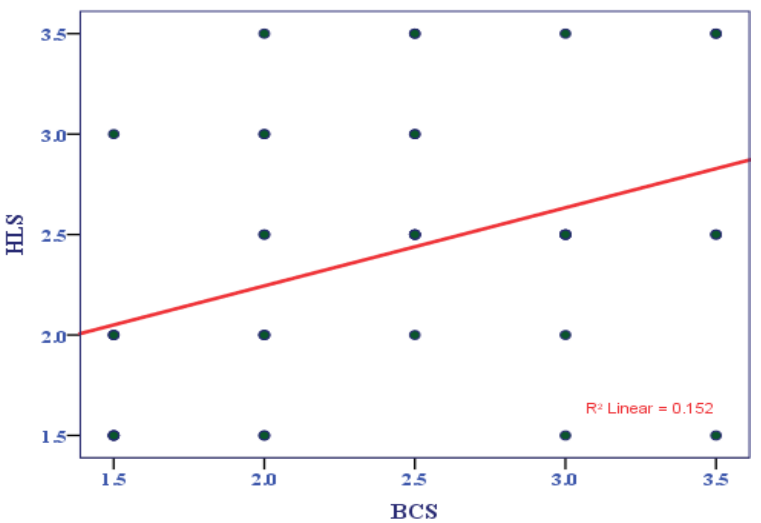

Fig.9 Correlation between HLS \& BCS

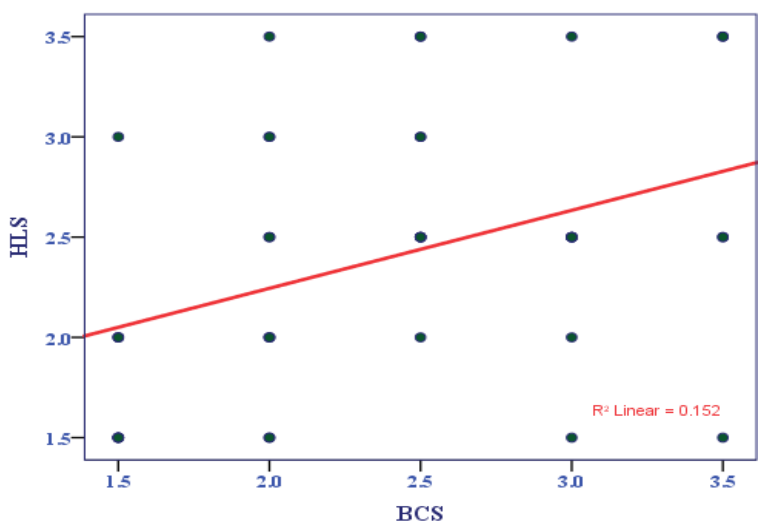

In this present study, LS of the animals from shed A were better as compared to the other sheds and worst at shed $\mathrm{B}$. The concrete floors of all sheds were found to be responsible for lameness. It was also revealed in this study that there was no regular practice of hoof trimming. Similar results were observed, where it was noticed that hoof lesions are main cause of lameness (Webster et al., 2001). It had also been associated with concrete flooring (Vokey et al., 2001). The critically lame animals in the sheds were not treated with special care and management (e.g. restricted movement, use of rubber mat flooring etc) which leads animals to a more critical condition. The observations were similar (Juarez et al., 2003) which revealed reduced walking activity leading to minimize the chance of lameness. The animals used to shift its weight from one leg to the other frequently to overcome the painful situation during lameness (Neveux et al., 2006).

Hock lesions in severe condition mostly turned into lameness in animals. Floor conditions of three sheds were the main reason for the hock lesion among the animals, where animals got hock lesion due to rough concrete floor. In a study (Main et al., 2003) similar results were found where it was concluded that lesions over joints occur because of deficiencies in the floor surface. Skin lesions on the legs of cattle likely to occur on areas where there are protrusions (Zurbrigg et al., 2005). When animals lie down, the soft tissue is compressed between 
these protrusions and the lying surface, resulting in an interruption of perfusion to the tissue.

In a study (Bodman and Rice, 1996) similar results were found which stated that proper cleaning and maintenance can reduce the bacterial contamination in dairy farms. They also identified key areas like hygiene, environment, cleanliness, clipped udders, water use, udder wash, pre dipping, udder drying etc. contributing to elevated bacterial counts and suggested practices which can inhibit bacterial growth. This study implied that mastitis incidents were more in such sheds where the cleanliness was poor due to increased pathogenic load.

In case of LS and BCS, there was significantly $\quad(\mathrm{P}<0.05) \quad$ high positive correlation, where the BCS value increasing accordingly with that of the increasing value of lameness score. It implies that an animal suffering in lameness condition that will show poor body condition, similarly an animal having a good BCS will not show any lameness. The animal with lameness condition consuming less that reflects on its body condition and makes the animal dull.

In a study (Blackie et al., 2011) stated that lame animals, for instance, were associated with a lower body condition and changes in behaviour which was supported by Bowell et al., (2003) and Ito et al., (2010). In another study (Espejo et al., 2006 and Roche et al., 2009) it was revealed that post-calving reduction in the body condition score is commonly associated with high milk production, reproduction and health issues such as lameness. Bewley et al., (2008) and Roche et al., (2009) stated that several management practices or facility designs (e.g. overstocking, cleanliness, feed bunk conditions, poor ventilation, found in this study) affect BCS by decreasing feed intake due to competition, limited feed bunk space, low feed quality (fermentations), decreased resting time and rumination, or heat stress conditions.

In comparison of lameness with the HLS in this study, it was found that the animals suffering from any HLS was lame which had been identified in its motion and standing condition. A strong proportional relation between HLS and lameness found, when the HLS increased; the LS was also increased. In a study (Cook et al., 2009) similar result was found in free-stall systems, where the link between stall design and lameness was most likely due to uncomfortable stalls resulting in hock injury. However, the effect also depends on the nature of the surface on which the animals stand. Similar study (Zurbrigg et al., 2005) stated that injuries to the hock and tarsal joints are characterized by hairless patches and lesions or swellings in extremely exposed areas that are sensitive to pressure when the animal is lying down on a hard and or abrasive surface with poor hygiene. Another study (Haley et al., 2001) stated that these lesions are painful and may force the animal to stand up or lie down for longer intervals which further leads to lameness and infective wound on hock.

It is concluded that the deficiencies observed on management practices, health of the animals and also in constructional side of each shed need proper attention.

Many animals showed very poor welfare score and poor productive performance on different concerned indicators, some showed average to superior condition. Proper hygiene practice, good feeding practice, regular hoof trimming, use of bedding materials and maintaining cleanliness can help to improve the overall health condition, productive performance and welfare status of the animals. 


\section{Acknowledgements}

The authors are highly thankful to the Hon'ble Vice-Chancellor, WBUAFS and Department of LFC, WBUAFS for providing the necessary facilities for this investigation.

\section{References}

Bewley J M and Schutz M M. 2008. Review: An interdisciplinary review of body condition scoring for farm cattle. The Professional Animal Scientist 24: 50729.

Blackie N, Amory J, Bleach E and Scaife J. 2011. The effect of lameness on lying behaviour of zero grazed Holstein dairy cattle. Applied Animal Behaviour Science 134: 85-91.

Bodman G R and Rice D N. 1996. Bacteria in Milk Sources and Control. University of Nebraska and the United States Department of Agriculture, U.S.A.

Bowell V A, Rennie L J, Tierney G, Lawrence A B and Haskell M J. 2003. Relationships between building design, management system and dairy cow welfare. Animal Welfare 12 (4): 547552.

Broom D M. 2001. Coping, stress and welfare in Coping with Challenge: Welfare in Animals including Humans. Proceedings of Dahlem Conference, 19. Berlin: Dahlem University Press.

Cook N B and Nordlund K. 2009. The influence of the environment on dairy cow behavior, claw health and herd lameness dynamics. The Veterinary Journal 179 (3): 360-369.

Drissler M, Gaworski M, Tucker C B and Weary D M. 2005. Freestall maintenance: Effects on lying behavior of dairy cattle. Journal of Dairy Science 88 (7): 2381-2387.

Espejo L A, Endres M I and Salfer J A. 2006. Prevalence of Lameness in High
Producing Holstein Cows Housed in Freestall Barns in Minnesota. Journal of Dairy Science 89 (8): 3052-3058.

Ferguson J D, Galligan D T and Thomsen N. 1994. Principal descriptors of body condition score in Holstein cows. Journal of Dairy Science 77 (9): 26952703.

Garnsworthy P C and Topps J H. 1982. The effect of body condition of dairy cow at calving on their food intake and performance when given complete diets. Animal Production 35 (1): 113.

Haley D B, de Passille A M and Rushen J. 2001. Assessing cow comfort: effects of two floor types and two tie stall designs on the behaviour of lactating dairy cows. Applied Animal Behaviour Science 71 (2): 105-117.

Ito $\mathrm{K}$, von Keyserlingk M A G, LeBlanc S J and Weary D M. 2010. Lying behavior as an indicator of lameness in dairy cows. Journal of Dairy Science 93 (8): 3553-3560.

Johnsen P F, Johannesson $\mathrm{T}$ and Sandoe P. 2001.Assessment of farm animal welfare at herd level: many goals, many methods. Acta Agriculturae Scandinavica. Section A. Animal Science 51 (1): 26-33.

Juarez S T, Robinson P H, De Peters E J and Price E O. 2003. Impact of lameness on behaviour and productivity of lactating Holstein cows. Applied Animal Behaviour Science 83 (1): 1-14.

Main D C, Whay H R, Green L E and Webster A J. 2003. Effect of the RSPCA Freedom Food Scheme on the welfare of dairy cattle. Veterinary Record 153 (8): 227-231.

Murray R D, Downham D Y, Clarkson M J, Faull W B, Hughes J W, Manson F J, Merritt J B, Russell W B, Sutherst J E and Ward W R. 1996. Epidemiology of lameness in dairy cattle: description and analysis of foot lesions. Veterinary 
Record 138: 586-591.

Neveux S, Weary D M, Rushen J, von Keyserlingk M A and de Passillé A M. 2006. Hoof discomfort changes how dairy cattle distribute their body weight. Journal of Dairy Science 89 (7): 2503-2509.

Regula G, Danuser J, Spycher B and Wechsler B. 2004. Health and welfare of dairy cows in different husbandry systems in Switzerland. Preventive Veterinary Medicine 66 (1-4): 247-264.

Roche J R, Friggens N C and Kay J K. 2009. Invited review: Body condition score and its association with dairy cow productivity, health, and welfare. Journal of Dairy Science 92 (12): 5769 5801.

Rushen J and De Passille A M. 1992. The scientific assessment of the impact of housing on animal welfare: a critical review. Canadian Journal of Animal Science 72 (4): 721-743.

Rushen J, Butterworth A and Swanson J C. 2011. Animal behavior and well-being symposium: farm animal welfare assurance: science and application. Journal of Animal Science 89:12191228.

Sandoe P, Giersing M H and Jeppesen L L. 1996. Concluding remarks and perspectives. Acta Agriculturae Scandinavica. Section A. Animal Science 27: 109-115.

Singh P J and Singh K R. 1994. A study of economic losses due to mastitis in India.
Indian Journal of Dairy Science 47: 265-272.

Snedecor G W and Cochran W G. 1967. Statistical methods. 6th Edition, The Iowa State University Press, Ames.

Sundrum A. 1996. Assessing livestock housing conditions in terms of animal welfare possibilities and limitations. pp. 238-246 in Proceedings of 4th International Symposium on Livestock farming systems, Foulum, Denmark.

Vokey F J, Guard C L, Erb H N and Galton D M. 2001. Effect of alley and stall surfaces on indices of claw and leg health in dairy cattle housed in free stall barn. Journal of Dairy Science 82 (12): 2686-2699.

Webster A J F. 2001. Effects of housing and two forage diets on the development of claw horn lesions in dairy cows at first calving and in first lactation. The veterinary Journal 162 (1): 56-65.

Wells S J, Trent A M, Marsh W E and Robinson R A. 1993. Prevalence and severity of lameness in lactating dairy cows in a sample of Minnesota and Wisconsin herds. Journal of the American Veterinary Medical Association 202: 78-82.

Zurbrigg K, Kelton D, Anderson N and Millman S. 2005. Stall dimensions and the prevalence of lameness, injury, and cleanliness on 317 tie-stall dairy farms in Ontario. Canadian Veterinary Journal 46 (10): 902-909.

\section{How to cite this article:}

Iftekar Rahaman, Rajarshi Samanta, Chittapriya Ghosh, Sanjoy Datta, Nilotpal Ghosh, Subhasish Biswas and Subhasish Batabyal. 2020. Association of Animal Health Indicators with Welfare Status in Frieswal Cattle at Organized Dairy Herd. Int.J.Curr.Microbiol.App.Sci. 9(10): 430-439. doi: https://doi.org/10.20546/ijcmas.2020.910.053 